\title{
LARVAL DEVELOPMENT IN LABORATORY OF CANCER AMPHIOETUS RATHBUN, IN COMPARISON WITH THOSE OF SEVEN OTHER SPECIES OF CANCER (DECAPODA, BRACHYURA)
}

\section{$\operatorname{AUTHOR}(\mathrm{S}):$}

Iwata, Fumio; Konishi, Kooichi

\section{CITATION:}

Iwata, Fumio ...[et al]. LARVAL DEVELOPMENT IN LABORATORY OF CANCER AMPHIOETUS RATHBUN, IN COMPARISON WITH THOSE OF SEVEN OTHER SPECIES OF CANCER (DECAPODA, BRACHYURA). PUBLICATIONS OF THE SETO MARINE BIOLOGICAL LABORATORY 1981, 26(4-6): 369-391

\section{ISSUE DATE:}

1981-09-30

URL:

http://hdl.handle.net/2433/176031

RIGHT: 


\title{
LARVAL DEVELOPMENT IN LABORATORY OF CANCER AMPHIOETUS RATHBUN, IN COMPARISON WITH THOSE OF SEVEN OTHER SPECIES OF CANCER (DEGAPODA, BRACHYURA)
}

\author{
Fumo IWATA and KooIGH KONISHI \\ Zoological Institute, Faculty of Science, Hokkaido \\ University, Sapporo 060, Japan
}

With Text-figures $1-8$ and Tables $1-10$

Recently the larval development has been described in detail successively in the following seven species of Cancer (Decapoda, Brachyura): Cancer magister Dana, C. productus Randall, $C$. gracilis Dana, C. antennarius Stimpson and C. anthonyi Rathbun from the Pacific coast of North America and $C$. irroratus Say and $C$. borealis Stimpson from the Atlantic coast of North America (Poole, 1966; Trask, 1970; Ally, 1975; Roesijadi, 1976; Sastry, 1977a, b; Anderson, 1978).

Cancer amphioetus Rathbun used for the present study is a dweller on the Pacific coast of Hokkaido, North Japan. The first zoea of this species has been observed already under laboratory conditions (Iwata, 1973). In the present study, the complete larval development including five zoeal stages and a megalopa are described in detail and the larval characters in the present species are compared with those in seven Cancer species hitherto reported.

\section{Material and Methods}

An ovigerous female of Cancer amphioetus used for the present study was collected between the tidemarks at Abuta on the Pacific coast of the southern Hokkaido, on June 25, 1979 and brought to our laboratory in Sapporo. A glass tank with sea water of 2 litres was used for culture of this crab. The tank was suspended in a water bath maintained at $15^{\circ} \mathrm{C}$. The first zoeae were hatched out on June 28, 1979 and 75 of them were then divided into three culture vessels, each containing sea water of 250 ml. Newly hatched Artemia nauplii were supplied as food. The sea water, that was transported from Oshoro Bay near Otaru, was kept at $18^{\circ} \mathrm{C}$ and renewed every day. Twelve hour illumination was given at intervals of the same time of darkness. Three kinds of antibiotics, 100 units $/ \mathrm{ml}$ penicillin $\mathrm{G}, 0.1 \mathrm{mg} / \mathrm{ml}$ streptomycin sulphate and $0.001 \mathrm{mg} / \mathrm{ml}$ amphotericin $\mathrm{B}$, were applied to the sea water.

The zoea and megalopa were fixed with $5 \%$ buffered formaldehyde for 1 hour and then transferred to $70 \%$ ethanol. Before dissection, they were cleared by keeping them in the lactophenol medium at least for 12 hours and the examination of the

Publ. Seto Mar. Biol. Lab., XXVI (4/6), 369-391, 1981.

(Article 21) 
larval characters was made on 10 or more specimens in each stage to make the morphological variation clear.

\section{Description of Larvae}

Cancer amphioetus passes through five zoeal instars and a megalopa in the larval development. The prezoeae occasionally found among the first zoeae were all inactive and died out within the day of hatching.

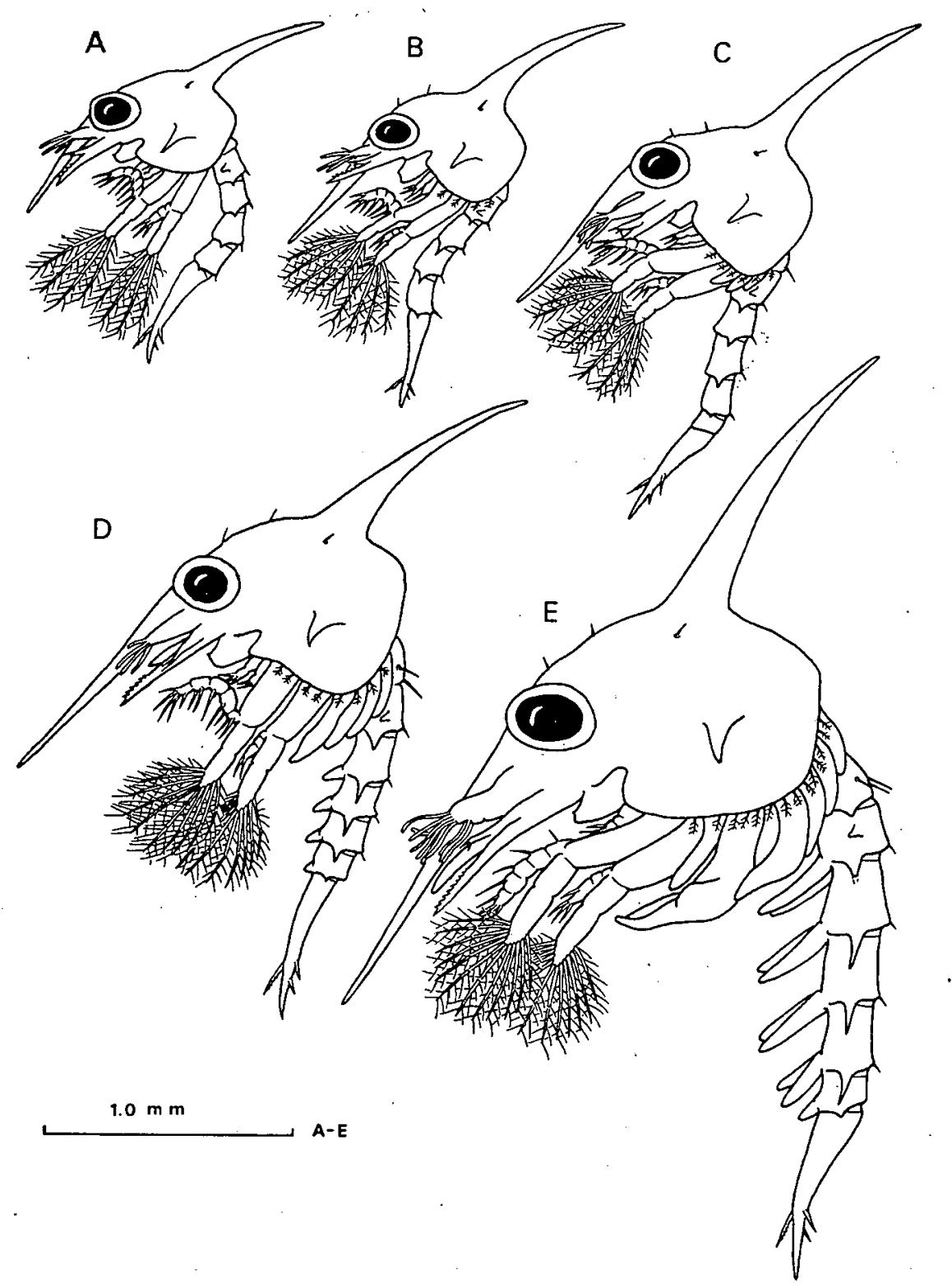

.Fig. 1. The first (A) through fifth (E) zoea of Cancer amphioetus, lateral view. 
The external features are essentially similar in all five zoeal stages (Fig. 1). Four spines are protruded from the cephalothorax; a long straight rostral spine, a long curved dorsal spine, and two shorter lateral spines. The abdomen is composed of five segments and the telson in the first and second zoeae, but an additional segment will appear between the 5 th segment and the telson in the third zoea (Fig. 2, C). The second segment bears a pair of short blunt knobs protruding laterally. Each segment overlaps laterally the succeeding one by forming a pointed projection on each side. The telson is bifurcated, each furca furnished with a dorsal and a lateral spur-like spine. The eyes are stalked in all but the first zoeal stage.

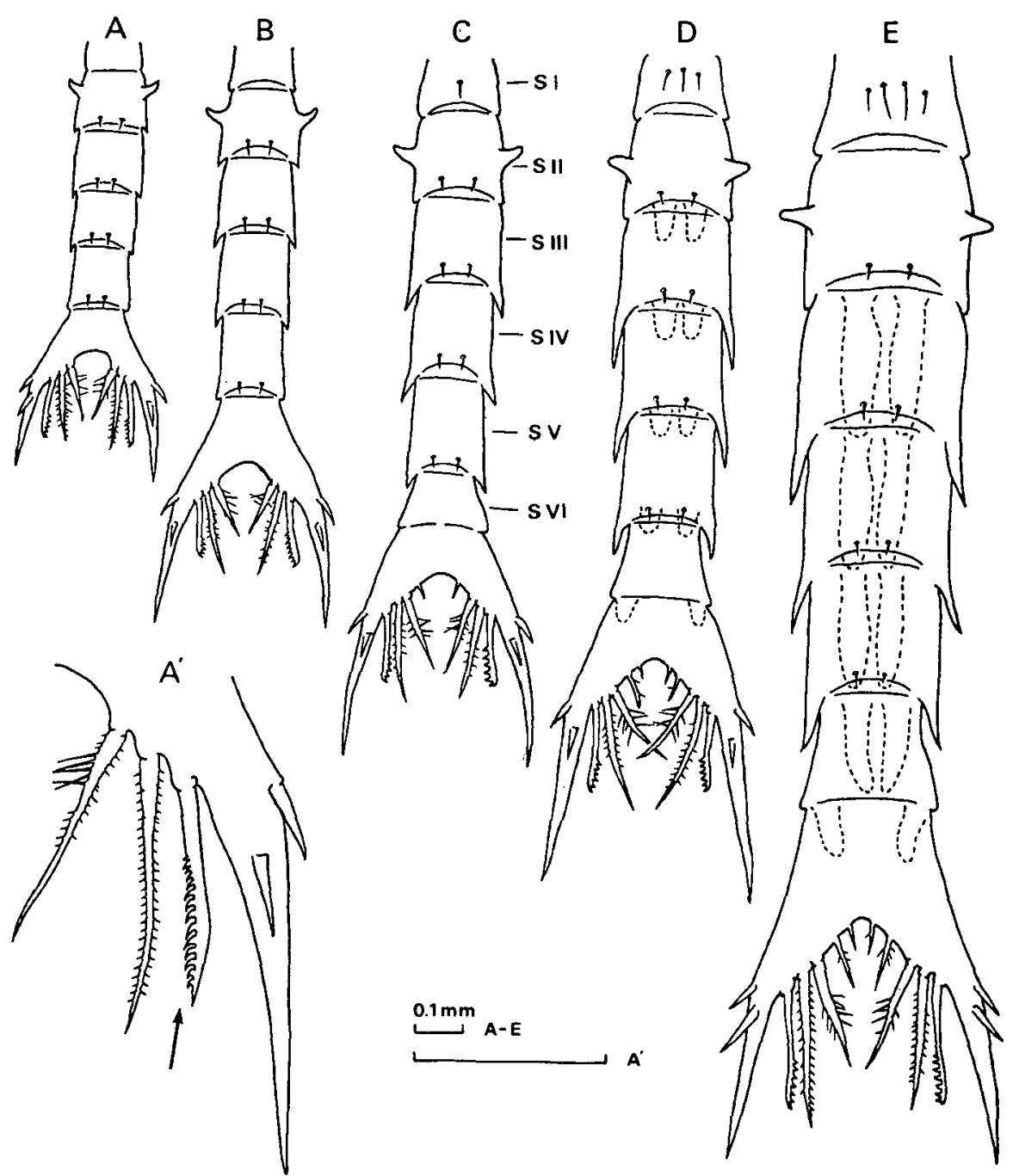

Fig. 2. Abdomen of the first (A) through fifth (E) zoea, dorsal view and right furca of telson ( $\left.\mathrm{A}^{\prime}\right)$ of Cancer amphioetus. SI: first abdominal segment, SII: second abdominal segment, SIII: third abdominal segment, $S I V$ : fourth abdominal segment, $S V$ : fifth abdominal segment, $S V I$ : sixth abdominal segment. 


\section{First Zoea}

The total length of the first zoea between the tips of the rostral and the dorsal spine is approximately $1.4 \mathrm{~mm}$ (Fig. 1, A). Two small setules are situated in a pair at the base of the dorsal spine and they remain constant through fifth zoeal stage.

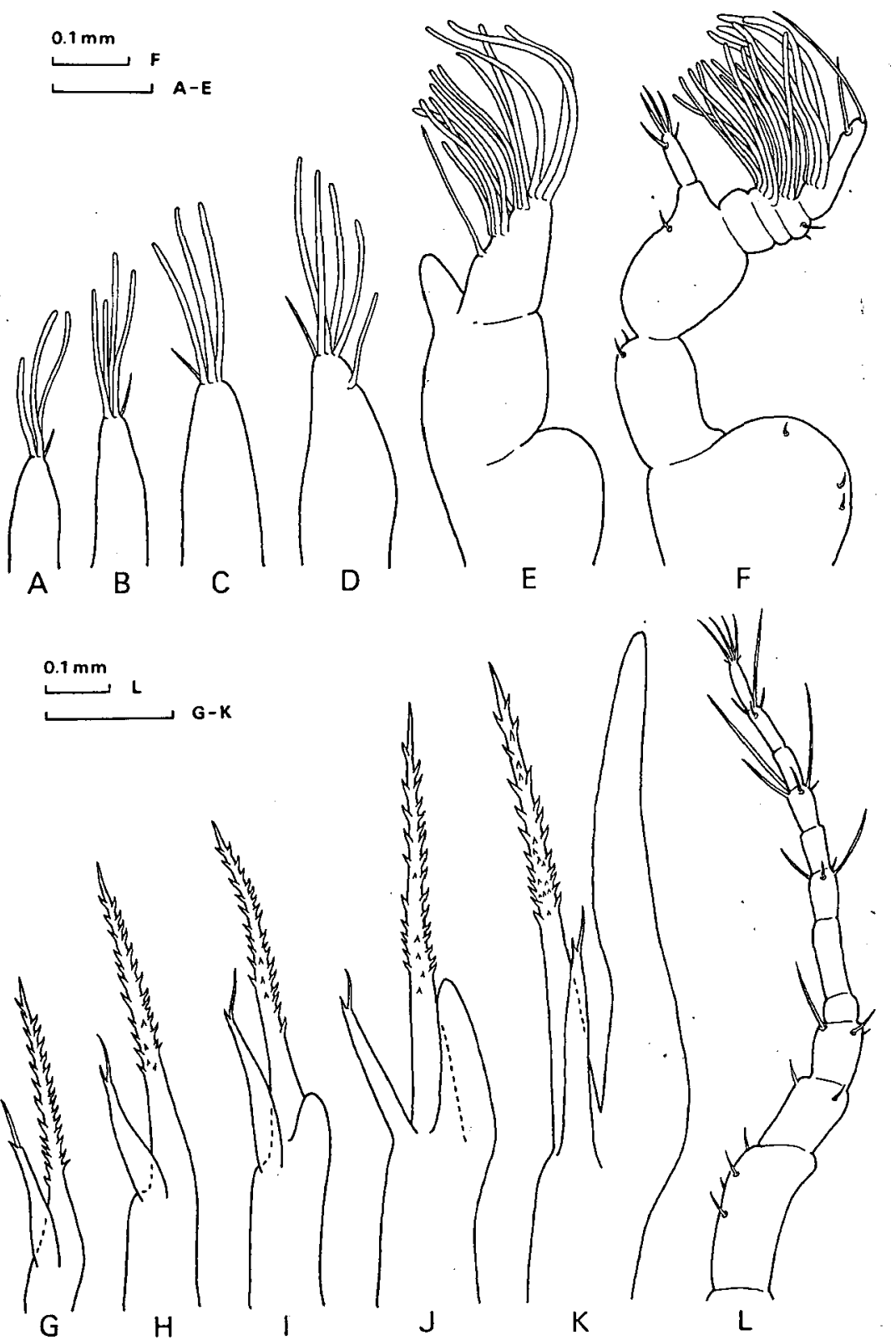

Fig. 3. Antennules (A-F) and antennae (G-L) of the first through fifth zoea and megalopa of Cancer amphioetus. 
Each fork of the telson is lined on its inner side with three spines of unequal length (Fig. 2, A); two internal spines are plumose and one external spine is dentated on its inside surface (Fig. $2 \mathrm{~A}^{\prime}$, pointed by arrow). The antennule bears two long and one short aesthetes and one short apical seta (Figs. 3, A). The protopodite of the antenna has two rows of spinules along its distal two thirds (Fig. 3, G). The exopodite has one long and one short terminal setae, this feature is constant throughout all zoeal stages. The mandible, composed of incisor and molar processes, differs slightly in structure between the left and right sides, especially in their denticulation (Fig. 4, A). The two-segmented endopodite of the maxillule bears three pairs of long spines on its terminal segment and an additional one on the proximal segment (Fig. 5, A). The spinal arrangement 1, 6 from proximal to distal is constant throughout the zoeal stages (Fig. 5, A-E). The basal and coxal endites are capped with five and six bristly spines respectively. The scaphognathite of the maxilla contains on its margin four plumose, hair-like setae and one long plumose posterior projection (Fig. 6, A). The bifurcate endopodite bears three spines on the end of each lobe, and this pattern remains constant through the fifth zoeal stage. Both the basal and coxal endites of the maxilla are bifurcate, each bearing four and three terminal spines respectively. The protopodite of the first maxilliped has nine spines arranged as 2, 2, 3, 2 from proximal to distal, and this pattern remains constant through the fifth zoeal stage (Fig. 7, A). The endopodite consists of five segments with a spinal pattern, constant through the third zoeal stage, of 2, 2, 1, 2, 5 from the proximal to distal segment. The exopodite is composed of two segments, the outer of which bears four long, plumose natatory hairs. The protopodite of the second maxilliped bears four spines arranged in a row, a pattern that remains constant through the fifth zoeal stage (Fig. 7, B). The endopodite has only three segments with one spine on each of the two proximal segments and five on the outer-most. The exopodite is

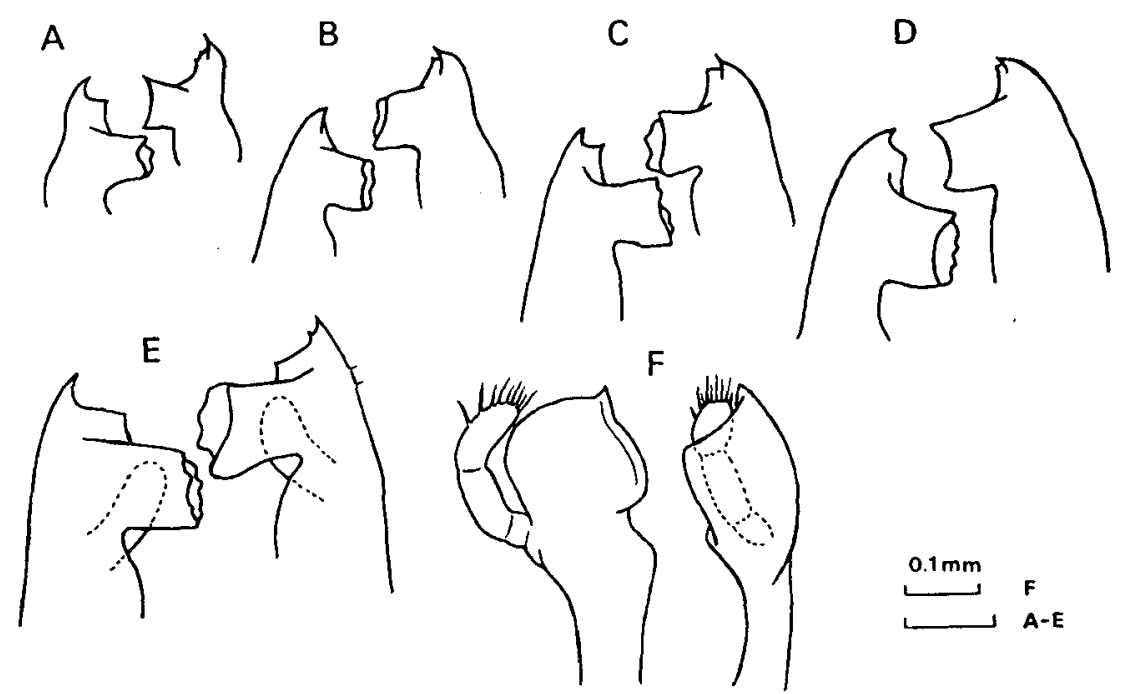

Fig. 4. Mandibles of the first through fifth zoea (A-E) and megalopa (F) of Cancer amphioetus. 
structured and furnished similarly as in the first maxilliped.

Remarks: The first zoea of Cancer amphioetus Rathbun reported by Iwata (1973) differs slightly from that described in the present paper in having the following features: the coxal endites of the maxilla have terminal spines arranged as 3,4 from distal to proximal; the protopodite and endopodite of the first maxilliped have eight spines arranged as 2, 2, 2, 2 in the former and thirteen ones arranged as 2, 2, 2, 2, 5 in the latter. These differences are, however, regarded as individual variations. Further, Iwata did not describe the dentation on the inside surface of the external spine on the inner side of each telsonal furca.

\section{Second Zoea}

The length of the second zoea between the tips of the rostral and the dorsal spine is approximately $1.6 \mathrm{~mm}$ (Fig. 1, B). Four short hairs are found on the posterior margin on each side of the carapace. The arrangement of spines on the telson is the same as in the first stage (Fig. 2, B). Two small setules are found in the frontal carapace between the rostral and dorsal spines, and they remain constant through the fifth zoeal stage (Fig. 1, B-E). Buds of the third maxilliped, cheliped and walking legs are visible under the carapace. The antennule now bears four (occasionally three) aesthetes of unequal length and one terminal seta (Fig. 3, B). Both the antenna and mandible are similar to those in the first zoeal stage (Fig. 3, H and Fig. 4, B). The protopodite of the maxillule bears one plumose seta near the middle of the outer edge, and this remains constant through the fifth zoeal stage (Fig. 5, B). Spines are increased to seven on both the basal and coxal endites. The scaphognathite of the maxilla is fringed with eleven (occasionally twelve) soft plumose setae (Fig. 6, B). Terminal spines on each lobe of the basal endite is four, while those on the two lobes of the coxal endite is four and three respectively from distal to proximal. The only change in the two maxillipeds is the increase of natatory hairs to six on the exopodite (Fig. 7, G).

\section{Third Zoea}

The length of the third zoea is roughly $2.0 \mathrm{~mm}$ (Fig. 1, C). Abdominal segments are increased to six and a pair of short additional spines appear near the inner-most pair of spines on the telsonal concavity (Fig. 2, C). Six (occassionally five, seven or eight) plumose setae are lining the posterior margin on each side of the carapace. Buds of the third maxilliped, cheliped and walking legs are partly exposed on the lateral side. The first abdominal segment bears a spinule on the mid-dorsal surface. The terminal portion of the antennule bears three long aesthetes and one short seta (Fig. 3, C). A small bud of the endopodite appears evidently for the first time on the protopodite of the antenna near the base of the exopodite (Fig. 3, I). The mandible is increased in size, otherwise as in the second zoea (Fig. 4, C). Seven (occasionally eight) terminal spines are present on the basal endite of the maxillule and 


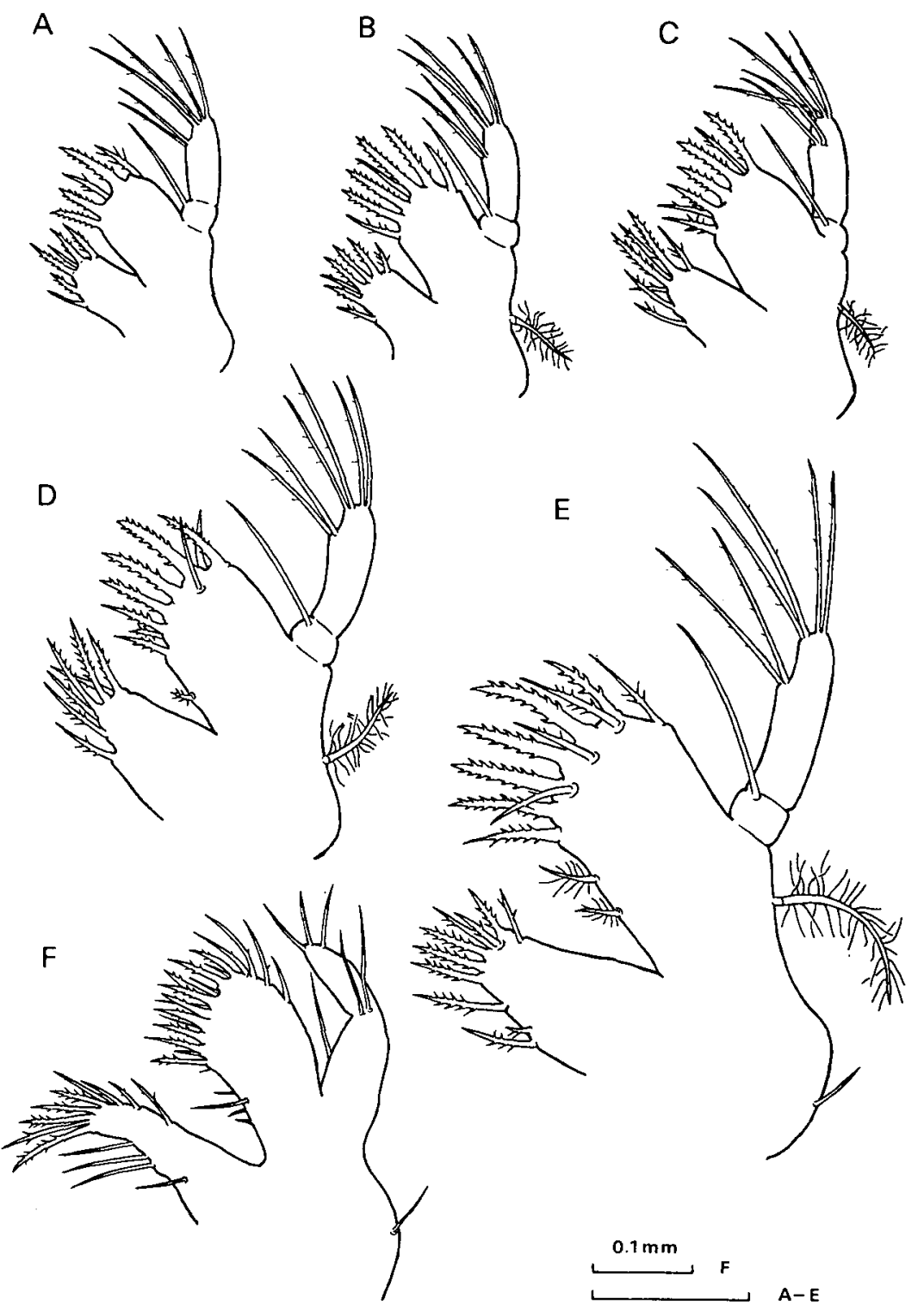

Fig. 5. Maxillules of the first through fifth zoea (A-E) and megalopa (F) of Cancer amphioetus.

seven (occasionally six) on the coxal endite (Fig. 5, G). The margin of the scaphognathite of the maxilla carries from seventeen to nineteen soft plumose hairs (Fig. 6 , C). Spines on the lobes of the basal endite are increased to five and four on the distal and proximal lobes respectively, but those on the coxal endite are decreased to three and three as in the first zoea. The maxillipeds remain unchanged, except for the addition of two natatory hairs, on the exopodite in each (Fig. 7, D). 


\section{Fourth Zoea}

The length of the fourth zoea is about $2.5 \mathrm{~mm}$ (Fig. 1, D). Sixteen (occasionally eighteen or twenty) plumose setae are lining the posterior margin of the carapace, and the biramous third maxilliped and segmented cheliped are largely exposed outside the carapace edge. A short spine is added to the group of spines on the inner edge of each furca of the telson (Fig. 2, D). This feature remains unchanged in the fifth zoeal stage. Small buds of the pleopods appear on the posteroventral margin of the second through the sixth abdominal segment for the first time. The first abdominal segment bears three spinules on its dorsal surface (Fig. 2, D). The antennule bears five aesthetes of unequal length and a short seta on its terminal end, the most exterior and shortest one of the former being located somewhat apart from the group of other four ones and a seta (Fig. 3, D).

The endopodite of the antenna is developed to be nearly as long as the exopodite (Fig. 3, J). The mandible is increased in size, otherwise as in the third zoea (Fig. $4, D)$. Spines on the basal and coxal endites of the maxillule are increased to ten (occasionally eleven or twelve) and seven (occasionally eight or nine) respectively (Fig. 5, D). Twenty-one to twenty-five soft plumose setae line the margin of the scaphognathite of the maxilla (Fig. 6, D). Spines on the lobes of the basal and coxal endites are increased to five and five in the former and to four and three in the latter from distal to proximal, respectively (Fig. 6, D). Occasionally, however, a total of nine, eleven or twelve spines may be found on the lobes of the basal endite, or eight spines in total on the lobes of the coxal endite. The natatory hairs on each maxilliped are increased to ten (Fig. 7, E). In addition, one more spine appears on the terminal segment of the endopodite of the first maxilliped, thus the spines are increased to six on that segment.

\section{Fifth Zoea}

The length of the fifth zoea is approximately $3.0 \mathrm{~mm}$ (Fig. 1, E). The posterior margin of the carapace is lined with fourteen (occasionally fifteen or sixteen) plumose setae on each side. The thoracic appendages still in the non-functional developing stage are fully protruded outside the carapace edge. The pleopod buds are also well developed. The first abdominal segment bears four spinules on its dorsal surface (Fig. 2, E). Of the three segments of the antennule, the proximal one is inflated externally and the terminal one is furnished with one long seta and three tiers of long aesthetes arranged in a pattern of four or five, three to five, and four or five from proximal to distal (Fig. 3, E). The rudimentary endopodite appears as a small bud at the inner distal corner of the middle segment. The tip of the endopodite of the antenna reaches distally nearly as far as that of the protopodite (Fig. 3, K). A small bud of the mandibular palp appears below the molar process (Fig. 4, E). Spines on the basal and coxal endites of the maxillule are twelve to eighteen and nine to eleven respectively (Fig. 5, E). In addition to the plumose seta on the outer edge 


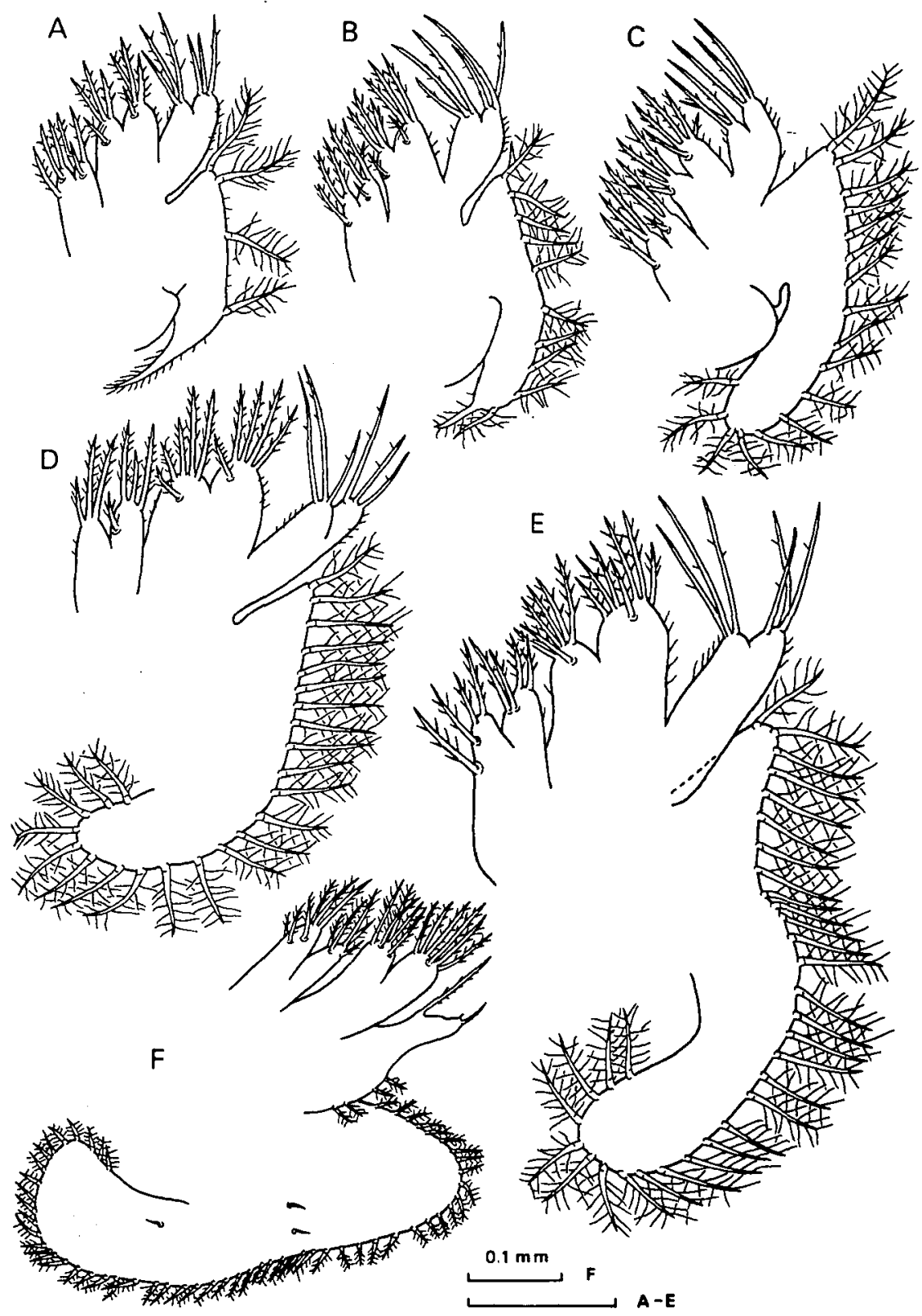

Fig. 6. Maxillae of the first through fifth zoea (A-E) and megalopa (F) of Cancer amphioetus.

of the protopodite near the base of the endopodite, a short simple seta appears at the base of the protopodite. On the maxilla, the soft plumose setae around the margin of the scaphognathite are increased to thirty to thirty-seven, while the spines on the lobes of the basal and coxal endites are arranged in groups of seven and six in the former, and four and four in the latter (Fig. 6, E), though a total of setae on 
the lobes of the basal and coxal endites may vary from twelve to fifteen in the former or may be nine in the latter. The exopodite of the first maxilliped bears eleven or twelve natatory hairs and that of the second twelve ones (Fig. 7, F).

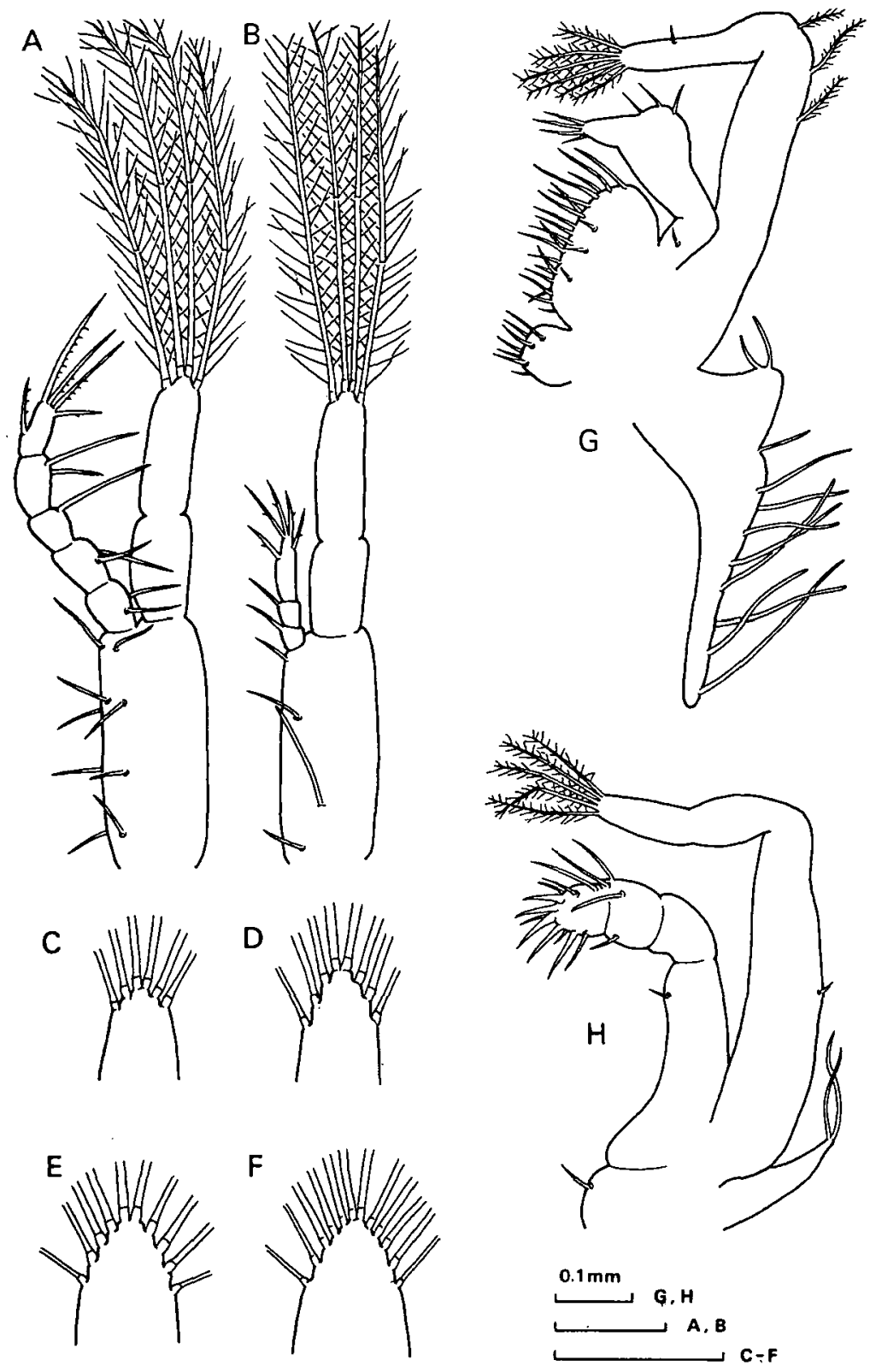

Fig. 7. First (A) and second (B) maxilliped of the first zoea, distal setae of exopodite of first and second maxillipeds of the second through fifth zoea (C-F), first $(G)$ and second $(H)$ maxillipeds of megalopa of Cancer amphioetus. 


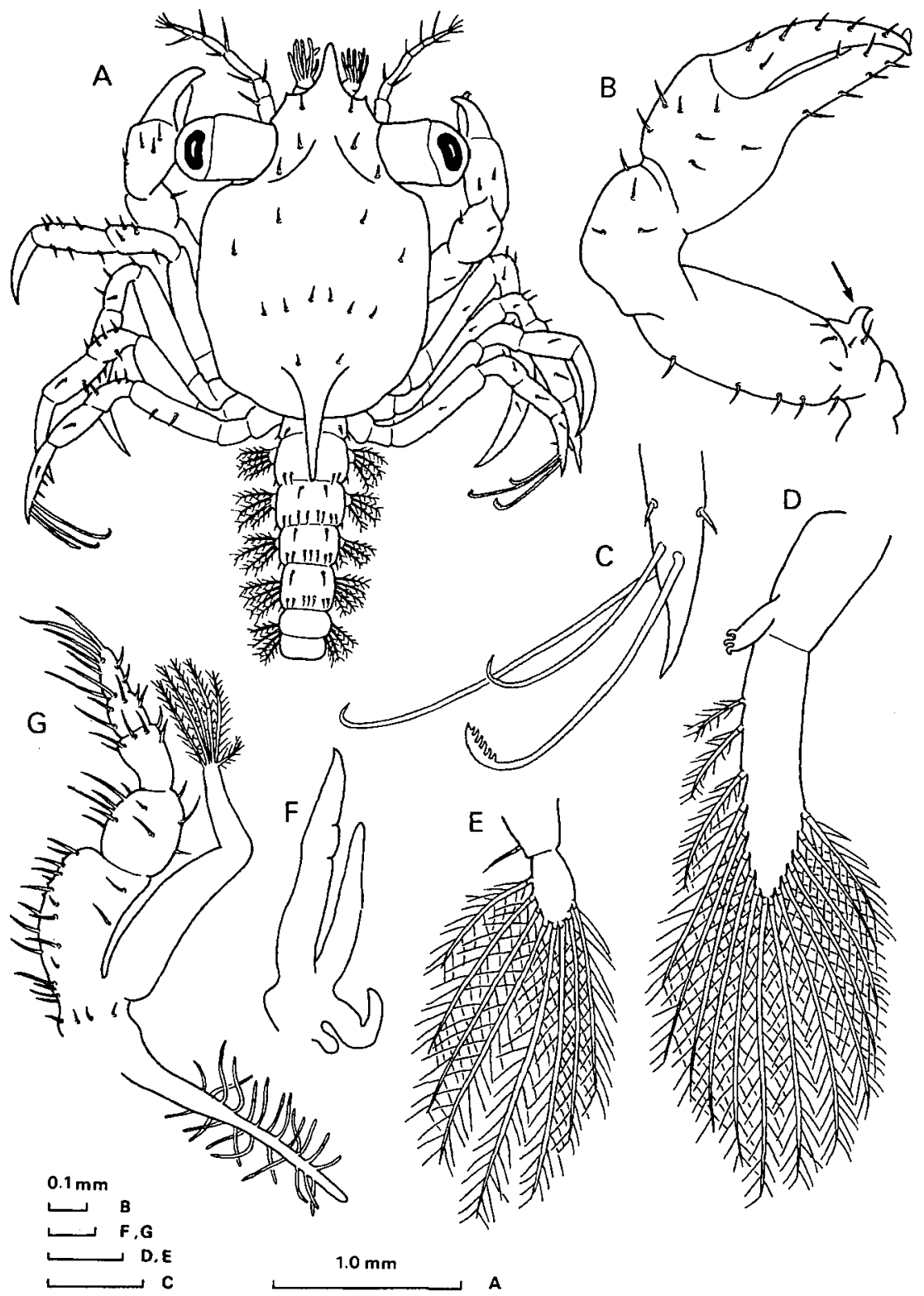

Fig. 8. Megalopa (A), cheliped of megalopa (B), feelers of fourth walking leg of megalopa (C), pleopod of second abdominal segment of meglaopa (D), uropod of megalopa (E), bud of third maxilliped of the fifth zoea $(F)$, and third maxilliped of megalopa $(G)$ of Cancer amphioetus.

\section{Megalopa}

The megalopa is approximately $3.3 \mathrm{~mm}$ long and $1.2 \mathrm{~mm}$ wide across the carapace (Fig. 8, A). The lateral spines have disappeared, but the rostral and dorsal ones are still remaining, though reduced. Eighteen to twenty setules are found on 
the dorsal surface of the carapace. The first to fifth abdominal segments are furnished with short spinules, distributed as $4,6,12,11$, and 11 respectively. The telson is flattened dorsoventrally and gently rounded on the lateral margin.

Of the three peduncular segments of the antennule, the proximal segment is much inflated externally, while the terminal one is now supporting two flagella (Fig. $3, F)$. The internal unsegmented flagellum carries five or six setae, while the external four-segmented flagellum bears eight to eleven, seven or eight, and five long aesthetes on the second, third and fourth segments respectively. The fourth segment is furnished distally with one long and one short thick spines. Each peduncular segment bears one, two and three spinules respectively from distal to proximal. Two spinules are found on the third segment of the four-segmented flagellum. The antenna consists of eleven segments distinctly separated and furnished with spines $4,2,3,0,0$, $4,0,5,0,4$, and 4 respectively from proximal to distal (Fig. 3, L). The mandibular palp is well developed, three-segmented, and bears eight or nine terminal spines (Fig. $4, F)$. The endopodite of the maxillule carries three terminal, two subterminal and one proximal spines, and a single simple spine is located on the protopodite near the base of the endopodite (Fig. 5, F). Twenty-three to twenty-six spines cap the basal endite and thirteen to sixteen similarly furnishing the coxal endite. On the maxilla, the scaphognathite is fringed with fifty-six fine plumose hairs (Fig. 6, F). All or most, leaving only two, of terminal spines are gone out on the endopodite, and newly three or four fine plumose hairs appear near its base. Two lobes of the basal endite bear each six terminal spines. The proximal lobe of the coxal endite carries six terminal spines and the distal lobe five. Occasionally, however, the basal endite may bear a total of thirteen to fifteen spines, while the coxal endite a total of ten to twelve.

The epipodite of the first maxilliped is lined with ten to thirteen long hair-like setae (Fig. 7, G). The protopodite bears a total of thirty spines on two lobes, twentythree and seven on the distal and basal lobes respectively. The endopodite bears four terminal, three subterminal, and one basal setae, while the exopodite is furnished terminally with six plumose setae and subterminally with a small spine. Further, three fine plumose hairs are found in the middle portion. The epipodite of the second maxilliped is less developed as compared with those of the first and third maxillipeds, and bears only two or three long hairs distally (Fig. 7, H). The foursegmented endopodite are furnished with one, four, and twelve spines on the first, third, and fourth segments respectively. The protopodite is single-lobed and bears a single spine. Five long plumose setae are furnishing the terminal end of the exopodite and a small spine in the basal half. The third maxilliped is well developed and carries twenty-four soft simple setae on the epipodite (Fig. 8, G). Additionally, four short spines are set across its base. The protopodite is single-lobed and bears a total of fifteen to seventeen spines. On the five segments of the endopodite, spines are distributed as $23,11,6,6$, and 9 respectively from proximal to distal. Six long terminal plumose setae are issued from the tip of the exopodite.

Fine setae are evident on the chelipeds and walking legs. Three remarkably 
long setae or feelers and two small spines are set on the dactylopodite of the fourth walking leg (Fig. 8, C). A characteristic hook-like projection is found on the ventral side of the basi-ischiopodite of the cheliped (Fig. 8, B; pointed by arrow). The pleopods of the second through the sixth abdominal segment are fringed with long, plumose setae (Fig. 8, D). There are sixteen setae on each pleopod of the second through the fifth abdominal segment, but only eight ones on the pleopod of the sixth segment. The endopodite of each pleopod, except the posterior-most pair, bears three small terminal hooks.

\section{Comparison of Larvae among the Eight Species of Cancer}

The larvae of Cancer amphioetus described above in detail are compared with those of seven other species so far studied; these include five species, the Dungeness crab $C$. magister, red crabs $C$. productus and $C$. gracilis, the rock crab $C$. antennarius, and the yellow crab $C$. anthonyi, from the Pacific coast of North America and two species, the rock crab $C$. irroratus and the Jonah crab $C$. borealis, from the Atlantic coast of North America.

In all the species above cited, the carapace of the zoea is provided with a rostral, a dorsal and a pair of lateral spines. In the megalopa, the rostral and dorsal spines are retained in all species, while the lateral spines remain only in two species, $C$. productus and $C$. antennarius. Buds of the thoracic appendages are exposed outside the carapace in the third ozea in C. magister, C. gracilis, C. borealis and C. amphioetus, in the fourth zoea in $C$. productus and $C$. antennarius, but in the fifth zoea in $C$. anthonyi and $C$. irroratus. In the megalopa, three setae on the dactylopodite of the fourth walking leg are present in all the species (Table I, G). In the first zoea of all the species, there are three spines on the inner side of each telsonal furca and two more spines are added to these in the fourth zoea (Table II). In the second and third

Table I. Number of setae or spines on respective appendages in megalopa.

\begin{tabular}{lccccccccc}
\hline & $\mathrm{A}$ & $\mathrm{B}$ & $\mathrm{C}$ & $\mathrm{D}$ & $\mathrm{E}$ & $\mathrm{F}$ & $\mathrm{G}$ & $\mathrm{H}$ & \multicolumn{1}{c}{} \\
\hline C. gracilis & 8 & $2(3), 8-11$ & 4 & $2-4,5$ & $16-20$ & $16-19$ & 3 & $3(2)$ & $17-19,17-19,17-18$, \\
& & & & & & & & & $14-16,7-9$ \\
C. antennarius & 9 & $13(10,3)$ & 4 & 0,5 & 12 & 20 & 3 & 3 & $19,18,19,15,9$ \\
C. anthonyi & 13 & 11 & 3 & $3,0,6$ & 17 & 20 & 3 & 3 & $16-17,17-18,16-17$, \\
& & & & & & & & & $15-16,9-10$ \\
C. amphioetus & $8-9$ & $10-13$ & $2-3$ & 0,6 & $15-17$ & 24 & 3 & 3 & $16,16,16,16,8$ \\
C. magister & 18 & 19 & 19 & 17,10 & 1,50 & 38 & 3 & $4-5$ & $32,32,32,28,22(19)$ \\
C. productus & 12 & 6 & 6 & 5,6 & 2,10 & 16 & 3 & $3-4$ & $21,19,19,19,12$ \\
C. irroratus & 9 & - & 17 & 3,6 & 17 & 9 & 3 & - & $15,15,13,11,9$ \\
C. borealis & 9 & - & 5 & 0,5 & 10 & 19 & 3 & - & $16,16,16,16,10$ \\
\hline
\end{tabular}

A: mandibular palp, B: epipodite of first maxilliped, C: epipodite of second maxilliped, D: exopodite of third maxilliped, E: protopodite of third maxilliped, F: epipodite of third maxilliped, G: dactylopodite of fourth walking leg, $\mathrm{H}$ : hooks on endopodite of pleopod, I: exopodite of pleopod. 
zoeae, however, the addition of spines is variable among these species. In all the species, buds of the pleopods on the second through the sixth abdominal segment come out in the fourth zoea. In the megalopa, number of setae on the distal end of pleopods is variable among the species (Table I, I). The abdominal segments of the first and second zoeae are five in all the species, while those of the third through the fifth zoea and of the megalopa are six in five species (Table III). The abdomen of $C$. magister is constantly composed of five segments throughout the larval stages, while in $C$. productus and $C$. irroratus the sixth abdominal segment is added in the fourth zoeal stage.

Table II. Number of spines on inner furca of telson.

\begin{tabular}{llllll}
\hline \hline & I & II & III & IV & V \\
\hline C. gracilis & 3 & 3 & 4 & 5 & 5 \\
C. antennarius & 3 & 3 & 4 & 5 & 5 \\
C. anthonyi & 3 & 3 & 4 & 5 & 5 \\
C. amphioetus & 3 & 3 & 4 & 5 & 5 \\
C. magister & 3 & 4 & 5 & 5 & 5 \\
C. productus & 3 & 3 & 5 & 5 & 5 \\
C. irroratus & 3 & 3 & 4 & 5 & 5 \\
C. borealis & 3 & 4 & 4 & 5 & 5 \\
\hline
\end{tabular}

I: first zoea, II: second zoea, III: third zoea, IV: fourth zoea, V: fifth zoea.

Table III. Number of abdominal segments.

\begin{tabular}{lcccccc}
\hline \hline & I & II & III & IV & V & Megalopa \\
\hline C. gracilis & 5 & 5 & 6 & 6 & 6 & 6 \\
C. antennarius & 5 & 5 & 6 & 6 & 6 & 6 \\
C. anthonyi & 5 & 5 & 6 & 6 & 6 & 6 \\
C. amphioetus & 5 & 5 & 6 & 6 & 6 & 6 \\
C. magister & 5 & 5 & 5 & 5 & 5 & 5 \\
C. productus & 5 & 5 & 5 & 6 & 6 & 6 \\
C. irroratus & 5 & 5 & 5 & 6 & 6 & 6 \\
C. borealis & 5 & 5 & 6 & 6 & 6 & 6 \\
\hline
\end{tabular}

Antennule: In C. magister, C. productus and $C$. anthonyi, the aesthetes are increased as $3,6,6,8$ from the first to the fourth zoeal stage respectively (Table IV, A). In the fifth zoea and megalopa, number of aesthetes on three tiers becomes variable among the species. The bud of endopodite comes out in the fifth zoea in all the species. In the megalopa, number of setae on the endopodite is variable among the species, though five and six setae occur in two species respectively; $C$. productus and $C$. antennarius for the former and $C$. gracilis and $C$. irroratus for the latter (Table IV, B). 
Table IV. Number of aesthetes on antennule (A), bud of endopodite of antennule and setae on antennule endopodite in megalopa (B).

(A)

\begin{tabular}{lllllll}
\hline \hline & I & II & III & \multicolumn{1}{c}{ IV } & \multicolumn{1}{c}{ V } & \multicolumn{1}{c}{ Megalopa } \\
\hline C. gracilis & 5 & 6 & 6 & $8(2,6)$ & $16-19(6,7-9,3-4)$ & $30-32(12-14,11,7)$ \\
C. antennarius & 3 & 5 & 4 & 6 & $14(3,7,4)$ & $24(10,6,8)$ \\
C. anthonyi & 3 & 6 & 6 & 8 & $17(3,8,6)$ & $32(15,10,7)$ \\
C. amphioetus & 3 & 4 & 3 & $5(1,4)$ & $11-15(4-5,3-5,4-5)$ & $22-26(8-11,7-8,5)$ \\
C. magister & 3 & 6 & 6 & $8(2,6)$ & $29(6,14,9)$ & $43(17,15,11)$ \\
C. productus & 3 & 6 & 6 & $8(2,6)$ & $24(6,12,6)$ & $30(13,9,8)$ \\
C. irroratus & 3 & 6 & 6 & 6 & $25(9,9,7)$ & $29(12,10,7)$ \\
C. borealis & 3 & 3 & 3 & $5(2,3)$ & $13(4,7,2)$ & $19(7,7,5)$ \\
\hline
\end{tabular}

(B)

\begin{tabular}{lcccccc}
\hline \hline & I & II & III & IV & V & Megalopa \\
\hline C. gracilis & - & - & - & - & + & 6 \\
C. antennarius & - & - & - & - & + & 5 \\
C. anthonyi & - & - & - & - & + & 7 \\
C. amphioetus & - & - & - & - & + & $5-6$ \\
C. magister & - & - & - & - & + & 9 \\
C. productus & - & - & - & - & + & 5 \\
C. irroratus & - & - & - & - & + & 6 \\
G. borealis & - & - & - & - & + & 4 \\
\hline
\end{tabular}

- : absent, +: emergence.

Antenna: In the first zoea, the eight species of Cancer are divided into two groups by number of setae on the exopodite: one group including $C$. gracilis, $C$. antennarius, $C$. anthonyi and $C$. amphioetus is defined by having two setae, while the other consisting of the remainders by having three setae (Table $\mathrm{V}, \mathrm{A}$ ). In all the species, the number of setae remains unchanged through the fifth zoeal stage. The bud of endopodite comes out in the third zoea in all the species and then in the megalopa it is transformed to a long eleven-segmented antenna furnished with spines definitely arranged specifically (Table VI, A). The spinal arrangement sectioned in ten, as reported in $C$. irroratus (Sastry, 1977a), is seemingly exceptional.

Mandible: The bud of the mandibular palp appears in the fifth zoea, and in the megalopa it becomes to be the palp, one to three-segmented and furnished with seven to eighteen spines; three species, $C$. antennarius, $C$. irroratus and $C$. borealis, have nine spines, while $C$. magister has eighteen (Table I, A).

Maxillule: In the first zoea, the eight species are divided into two groups by number of spines on the distal end of the two-segmented endopodite: the one group consisting of $C$. gracilis, $C$. antennarius and $C$. anthonyi is definable by having five spines, while the other including the remainders by having six (Table V). Exceptionally, four spines were reported in the first zoea of $C$. antennarius (Roesijadi, 1976). In 
Table V. Number of setae or spines on exo- and endopodite of zoeal appendages.

\begin{tabular}{llcccc}
\hline & A & B & C & D & E \\
\hline C. gracilis & 2 & 1,5 & $6(3+3)$ & $2,2,1,2,5(6)$ & $1,1,5$ \\
C. antennarius & 2 & 1,5 & $6(3+3)$ & $2,2,1,2,5(6)$ & $1,1,5$ \\
C. anthonyi . & 2 & 1,5 & $6(3+3)$ & $2,2,1,2,5(6)$ & $1,1,5$ \\
C. amphioetus & 2 & 1,6 & $6(3+3)$ & $2,2,1,2,5(6)$ & $1,1,5:$ \\
C. magister. & 3 & $1,6$. & $7(4+3)$ & $3,2,1,2,5(6)$ & $1,1,5$. \\
C. productus & 3 & 1,6 & $7(4+3)$ & $3,2,1,2,5(6)$ & $1,1,5$ \\
C. irroratus. & 3 & 1,6 & $8(5+3)$ & $3,2,1,2,5(6)$ & $1,1,5$ \\
C. borealis & 3 & 1,6 & $8(5+3)$ & $3,2,1,2,5(6)$ & $1,1,5$. \\
\hline
\end{tabular}

A: antennal exopodite, B: endopodite of maxillule, $\mathrm{C}$ : endopodite of maxilla, $\mathrm{D}$ : endopodite of first maxilliped, $\mathrm{E}$ : endopodite of second maxilliped.

all the species, the number of spines remains unchanged through the fifth zoeal stage. In the megalopa, the endopodite is one to three-segmented and furnished with a definite number of spines in respective species, though the spinal arrangement of 1 , 6 or $1,1,3$ occurs in two species, $C$. irroratus and $C$. borealis or $C$. antennarius and $C$. magister respectively (Table VI, B).

In the first zoea of all the species, the basal endite has five spines, and then two more spines are added in the second zoea (Table VII, A). In the third through the fifth zoea, however, the spines are increased variably among the species, though in each of these stages the same number of spines may be seen in two or more species. For instance, an increment pattern of spines through the fifth zoea as 5, 7, 8, 12 and 15 is common to three species, C. gracilis, C. antennarius and C. anthonyi. Record of fourteen spines in the fifth zoea of $C$. antennarius (Roesijadi, 1976) is clearly exceptional. In the megalopa, the number of spines on the basal endite is variable among the species. Further, in the following four species, C. magister, C. productus, C. anthonyi and $C$. amphioetus, the number of spines may be variable among the specimens. In $C$. gracilis and $C$. irroratus, the coxal endite has seven spines in the first zoea, while in the remainders it has six spines (Table VII, B). The increment of spines in the

Table VI. Number of setae or spines on the endopodite of respective appendages in megalopa.

\begin{tabular}{|c|c|c|c|c|c|c|}
\hline & A & B & $\mathbf{C}$ & $\mathrm{D}$ & $\mathrm{E}$ & $\mathbf{F}$ \\
\hline C. gracilis & $5,2,4,0,0,4,0,5,0,4,5$ & $3(1,2)$ & $3-4(2), 1$ sp. & 1,3 & $1-1,1,6-7,9$ & $\begin{array}{l}23-27,13,10-12 \\
10-13,9\end{array}$ \\
\hline C. antennarius & $4,2,4,0,0,4,0,5,0,4,4$ & $5(1,1,3)$ & 1 & 0,5 & $0,7,8$ & (5), $10,6,8,7$ \\
\hline C. anthonyi & $5,2,3,0,0,4,0,5,0,5,5$ & $4(1,3)$ & 3 & $1,3,3$ & $2,1,7,10$ & $27,14,12,13,10$ \\
\hline C. amphioetus & $4,2,3,0,0,4,0,5,0,4,4$ & $6(1,2,3)$ & 3-4ps., 0-2sp. & $1,3,4$ & $1,0,4,12$ & $23,11,6,6,9$ \\
\hline C. magister & $11,11,8,0,2,7,0,6,2,5,5$ & $5(1,1,3)$ & $8-10$ & $7,8-9$ & $7,6,20,14$ & $50,29,24,14,17$ \\
\hline C. productus. & $5,4,4,0,0,3,2,3,1,3,5$ & $5(1,3,1)$ & 1 & 5,4 & $5,0,7,7$ & $25,10,7,11,23$ \\
\hline C. irroratus & $0,2,2,4,0,3,0,6,4,4$ & $7(1,6)$ & 1 & 3,3 & $0,2,6,8$ & $21,10,10,6,8$ \\
\hline C. borealis & $0,1,3,0,0,5,0,3,0,4,5$ & $7(1,6)$ & 4ps. & 3,2 & $1,1,7,8$ & $19,9,9,12,8$ \\
\hline
\end{tabular}

A: antenna, B: maxillule, C: maxilla, D: first maxilliped, E: second maxilliped, F: third maxilliped. ps: plumose seta, sp: spine. 
second through the fifth zoeal stage and in the megalopa is variable among the species, though the same number of spines may occur in two or more species in respective stages.

In the second zoea of all the species, the protopodite has a plumose seta on its dorsal margin and this will remain constant through the fifth zoea. Exceptionally, two setae are recorded on the protopodite in the fourth and fifth zoeae of $C$. gracilis and in the fifth zoea of $C$. amphioetus. In the megalopa, the existence of a single simple seta on the protopodite is common to five species, but $C$. gracilis has two or occasionally three setae, and C. magister and C. productus have three ones (Table VII, G).

Maxilla: In the first zoea, the eight species may be classified into three groups by number of spines on the bilobed endopodite: the first group including C. gracilis, $C$. antennarius, $C$. anthonyi and $C$. amphioetus, is defined by having six spines arranged as 3,3 ; the second including $C$. magister and $C$. productus by seven spines arranged as 4, 3 from distal to proximal; and the last consisting of $C$. irroratus and $C$. borealis by eight spines arranged as 5, 3 from distal to proximal (Table $V, C$ ). In all the species, the number of spines above cited remains unchanged through the fifth zoeal stage. In the megalopa, the number of spines is reduced, less than in the zoeal stages, and variable among the species, though the three species, $C$. antennarius, $C$. productus and C. irroratus, are similarly provided with only a single spine (Table VI, C). In the first zoea, the bilobed basal endite is furnished with eight spines arranged as 4, 4 in two species, $C$. anthonyi and $C$. amphioetus, but with nine spines arranged as 4, 5 from distal to proximal in the other six species (Table VIII, A). The increment of spines in the second through the fourth zoeal stage is rather gentle, but it is remarkable in many of them in the fifth zoeal stage and megalopa. In respective larval stages, however, the same number of spines may occur in two or more species. In the first zoea, the coxal endite has seven spines arranged as 4,3 from distal to proximal in $C$. magister, $C$. productus and $C$. irroratus and six spines arranged as 3, 3 in the remainders (Table VIII, B). In all the species, the increment of spines throughout the larval stages is not so remarkable as in the case of the basal endite. In C. antennarius, six spines are retained throughout the whole zoeal stages and then in the megalopa two spines are added for the first time. In the first zoea, the scaphognathite has three setae in C. magister and $C$. antennarius, but four in the remainders (Table VIII, G). In all the species, the increment of setae throughout the larval stages is very remarkable, and accompanied in six species with individual variations.

First maxilliped: In the first zoea, the eight species can be divided into two groups by the spinal arrangement on the endopodite: the one group composed of C. gracilis, $C$. antennarius, $C$. anthonyi and $C$. amphioetus has twelve spines arranged as $2,2,1,2,5$ from proximal to distal, while the other including the remainders has thirteen spines arranged as 3, 2, 1, 2, 5 (Table V, D). The distal segment of the endopodite, however, bears one more spine in the fifth zoea in $C$. magister and $C$. irroratus and in the fourth and fifth zoeae in the remainders. In the megalopa, the number of spines on the two or three-segmented endopodite is variable throughout the whole species (Table VI, D). In the first zoea of all the species, the exopodite 
is furnished distally with four plumose setae and in each of the successive zoeal stages generally two more setae are added regularly (Table IX, A), though in C. gracilis, $C$. antennarius and $C$. anthonyi, eleven setae are recorded in the fifth zoea. In the megalopa, the setae on the distal end of the exopodite are considerably less than in the fifth zoeal stage, and five or six setae occur in two or more species. In the first zoea, the spinal arrangement on the protopodite is 2, 2, 3, 2 from proximal to distal in C. gracilis, $C$. antennarius and $C$. amphioetus, while it is $3,2,2,2$ in $C$. irroratus and $C$. borealis (Table IX, B). In $C$. magister, $C$. gracilis and $C$. amphioetus, the spinal arrangement remains unchanged through the fifth zoeal stage. In the megalopa, the bilobed

Table VII. Number of spines on basal (A) and coxal (B) endites and protopodite (C) of maxillule. (A)

\begin{tabular}{lcccccc}
\hline & I & II & III & IV & V & Megalopa \\
\hline C. gracilis & 5 & 7 & 8 & 12 & 15 & 26 \\
C. antennarius & 5 & 7 & 8 & 12 & 14 & 17 \\
C. anthonyi & 5 & 7 & 8 & 12 & 15 & $26-38$ \\
C. amphioetus & 5 & 7 & $7-8$ & $10-12$ & $12-18$ & $23-26$ \\
C. magister & 5 & 7 & 9 & 14 & $21-23$ & $38-43$ \\
C. productus & 5 & 7 & 9 & 13 & 17 & $30-32$ \\
C. irroratus & 5 & 7 & 8 & 10 & 18 & 23 \\
C. borealis & 5 & 7 & 8 & 11 & 12 & 14 \\
\hline
\end{tabular}

(B)

\begin{tabular}{lllcccc}
\hline \hline & I & II & III & IV & V & Megalopa \\
\hline C. gracilis & 7 & 7 & 7 & 8 & 10 & $15(14)$ \\
C. antennarius & 6 & 6 & 8 & 6 & 7 & 11 \\
C. anthonyi & 6 & 7 & 7 & 9 & 10 & 16 \\
C. amphioetus & 6 & 7 & $6-7$ & $7-9$ & $9-11$ & $13-16$ \\
C. magister & 6 & 6 & 8 & 11 & 16 & $29-31$ \\
C. productus & 6 & 6 & 8 & 9 & 10 & $15-17$ \\
C. irroratus & 7 & 7 & 7 & 7 & 10 & 10 \\
C. borealis & 6 & 6 & 6 & 9 & 10 & 11 \\
\hline
\end{tabular}

(C)

\begin{tabular}{lllllll}
\hline \hline & I & II & III & IV & V & Megalopa \\
\hline C. gracilis & - & 1 & 1 & 2 & 2 & $2(3)$ \\
C. antennarius & - & 1 & 1 & 1 & 1 & 1 \\
C. anthonyi & - & 1 & 1 & 1 & 1 & 1 \\
C. amphioetus & - & 1 & 1 & 1 & 2 & 1 \\
C. magister & - & 1 & 1 & 1 & 1 & 3 \\
C. productus & - & 1 & 1 & 1 & 1 & 3 \\
C. irroratus & - & 1 & 1 & 1 & 1 & 1 \\
C. borealis & - & 1 & 1 & 1 & 1 & 1 \\
\hline
\end{tabular}


Table VIII. Number of setae or spines on basal (A) and coxal (B) endites and scaphognathite (C) of maxilla.

(A)

\begin{tabular}{lcrrrrl}
\hline \hline & I & II & III & IV & V & \multicolumn{1}{c}{ Megalopa } \\
\hline C. gracilis & $9(4+5)$ & $9(4+5)$ & $10(5+5)$ & $11(6+5)$ & $15(8+7)$ & $8-9,9-9,8-8$ \\
C. antennarius & $9(4+5)$ & $9(4+5)$ & $10(5+5)$ & $12(6+6)$ & $16(8+8)$ & $17(9+8)$ \\
C. anthonyi & $8(4+4)$ & $10(5+5)$ & $10(5+5)$ & $11(6+5)$ & $15(8+7)$ & $18-19(10,8-9)$ \\
C. amphioetus & $8(4+4)$ & $8(4+4)$ & $9(5+4)$ & $10(5+5)$ & $13(7+6)$ & $12(6+6)$ \\
C. magister & $9(4+5)$ & $10(5+5)$ & $12(6+6)$ & $16(8+8)$ & $24(13+11)$ & $36-40(17+19-23)$ \\
C. productus & $9(4+5)$ & $10(5+5)$ & $12(6+6)$ & $12(6+6)$ & $16(8+8)$ & $22(11+11)$ \\
C. irroratus & $9(4+5)$ & $10(5+5)$ & $12(6+6)$ & $13(6+7)$ & $18(19+8)$ & $18(9+9)$ \\
C. borealis & $9(4+5)$ & $9(5+4)$ & $10(5+5)$ & $11(5+6)$ & $14(7+7)$ & $18(10+8)$ \\
\hline
\end{tabular}

(B)

\begin{tabular}{lcccccc}
\hline & I & II & III & IV & V & Megalopa \\
\hline C. gracilis & $6(3+3)$ & $6(3+3)$ & $7(4+3)$ & $7(4+3)$ & $8(4+4)$ & $9(2+7)$ \\
C. antennarius & $6(3+3)$ & $6(3+3)$ & $6(3+3)$ & $6(3+3)$ & $6(3+3)$ & $8(3+5)$ \\
C. anthonyi & $6(3+3)$ & $6(3+3)$ & $7(4+3)$ & $7(4+3)$ & $7(4+3)$ & $10(6+4)$ \\
C. amphioetus & $6(3+3)$ & $7(4+3)$ & $6(3+3)$ & $7(4+3)$ & $8(4+4)$ & $11(5+6)$ \\
C. magister & $7(4+3)$ & $7(4+3)$ & $7(4+3)$ & $7(4+3)$ & $10(5+5)$ & $16(8+8)$ \\
C. productus & $7(4+3)$ & $7(4+3)$ & $7(4+3)$ & $7(4+3)$ & $8(4+4)$ & $12(6+6)$ \\
C. irroratus & $7(4+3)$ & $7(4+3)$ & $7(4+3)$ & $7(4+3)$ & $10(5+5)$ & $10(5+5)$ \\
C. borealis & $6(3+3)$ & $8(5+3)$ & $7(4+3)$ & $7(4+3)$ & $7(4+3)$ & $11(5+6)$ \\
\hline
\end{tabular}

(G)

\begin{tabular}{lcccccc}
\hline & I & II & III & IV & V & Megalopa \\
\hline C. gracilis & 4 & 11 & $17-19$ & $23-27$ & $23-27$ & $53-59$ \\
C. antennarius & 3 & 11 & 18 & 24 & 24 & $53-55$ \\
C. anthonvi & 4 & $8-18$ & $16-19$ & $22-26$ & $22-26$ & $47-53$ \\
C. amphioetus & 4 & 11 & $17-19$ & $21-25$ & $30-37$ & 56 \\
C. magister & 3 & 11 & 19 & $27-32$ & $49-50$ & $110-124$ \\
C. productus & 4 & 11 & 19 & 25 & $37-38$ & $62-124$ \\
C. irroratus & 4 & 11 & 11 & 26 & 38 & 46 \\
C. borealis & 4 & 11 & 11 & 21 & 29 & $44-55$ \\
\hline
\end{tabular}

protopodite is furnished with many spines specifically variable in number. The epipodite bears a definite number of setae, different from species to species (Table $\mathrm{I}, \mathrm{B})$, though in $C$. irroratus and $C$. borealis no records are available as to this feature.

Second maxilliped: In all the species, the spinal arrangement on the endopodite is $1,1,5$ from proximal to distal, and this remains unchanged through the fifth zoeal stage (Table V, E). Exceptionally, seven spines are recorded on the distal end of the endopodite in the fifth zoea of $C$. irroratus (Sastry, 1977a). In the megalopa, however, the spinal arrangement on the four-segmented endopodite is quite specific 
and available to identify the larvae with certainty (Table VI, E). In the first żoea, the exopodite bears distally four plumose setae in all the species and regularly two more setae are added successively in the second through the fifth zoeal stage (Table $\mathrm{X}, \mathrm{A}$ ), although thirteen setae are recorded in the fifth zoea of $C$. magister and $C$. productus and the number of setae is a little variable in $C$. amphioetus in the third and the fourth zoea. In the megalopa, the distal setae are much less than in zoeal stages, and thus five setae occur in six species (Table X, A). In C. productus, C. gracilis: and C. amphioetus, the spinal arrangement on the protopodite is constantly $1,1,1,1$ through the fifth zoea (Table X, B). In the megalopa, the number of setae on the epipodite is variable from species to species, though four setae occur in C. gracilis and C. antennarius (Table I, C).

Third maxilliped: In the megalopa of all the species, the spinal arrangement on the five-segmented endopodite is quite specific as in the case of the second maxilliped (Table VI, F). On the two-segmented exopodite, the number of setae is variable among the species, but five setae occur in two species, $C$. antennarius and $C$. borealis (Table I, D). The number of setae on the epipodite is also variable among the species, though twenty setae occur in two species, $C$. antennarius and $C$. anthonyi (Table I, F).

Table IX. Number of setae or spines on exopodite (A) and protopodite (B) of first maxilliped.

(A)

\begin{tabular}{lcccccc}
\hline \hline & I & II & III & IV & V & Megalopa \\
\hline C. gracilis & 4 & 6 & 8 & 10 & 11 & $2-4,5$ \\
C. antennarius & 4 & 6 & 8 & 10 & 11 & 3,4 \\
C. anthonyi & 4 & 6 & 8 & 10 & 11 & $3,3,5$ \\
C. amphioetus & 4 & 6 & 8 & 10 & $11-12$ & $3,1,6$ \\
C. magister & 4 & 6 & 8 & 10 & 12 & $2,2,7$ \\
C. productus & 4 & 6 & 8 & 10 & 12 & 3,6 \\
C. irroratus & 4 & 6 & 8 & 10 & 12 & 3,4 \\
C. borealis & 4 & 6 & 8 & 10 & 12 & 2,5 \\
\hline
\end{tabular}

(B)

\begin{tabular}{lcccccl}
\hline & I & II & III & IV & V & Megalopa \\
\hline C. gracilis & $2,2,3,2$ & $2,2,3,2$ & $2,2,3,2$ & $2,2,3,2$ & $2,2,3,2$ & $14,20-23$ \\
C. antennarius & $2,2,3,2$ & $2,2,2,3$ & $2,2,4,1$ & $2,2,3,1$ & $1,2,2,2,2$ & 10,23 \\
C. anthonyi & $2,2,2,2$ & $2,2,2,2$ & $2,2,2,2$ & $2,2,3,2$ & $1,2,3,2$ & 20,15 \\
C. amphioetus & $2,2,3,2$ & $2,2,3,2$ & $2,2,3,2$ & $2,2,3,2$ & $2,2,3,2$ & 7,23 \\
C. magister & $2,2,2,3$ & $2,2,2,3$ & $2,2,2,3$ & $2,2,2,3$ & $2,2,2,3$ & numerous \\
C. productus & $2,2,3,3$ & $2,2,2,3$ & $2,2,2,3$ & $1,1,3,3$ & $2,2,2,3$ & 16,22 \\
C. irroratus & $3,2,2,2$ & $3,2,2,2$ & $3,2,2,3$ & $3,2,2,2$ & $3,2,2,2$ & 19,29 \\
C. borealis & $3,2,2,2$ & $3,2,3.2$ & $3,2,2,3$ & $3,2,1,1$ & $3,2,2,3$ & 12,20 \\
\hline
\end{tabular}


Table X. Number of setae or spines on exopodite (A) and protopodite (B) of second maxilliped.

(A)

\begin{tabular}{lcccccc}
\hline \hline & I & II & III & IV & V & Megalopa \\
\hline C. gracilis & 4 & 6 & 8 & 10 & 12 & $1(2), 5$ \\
C. antennarius & 4 & 6 & 8 & 10 & 12 & 4 \\
C. anthonyi & 4 & 6 & 8 & 10 & 12 & 5 \\
C. amphioetus & 4 & 6 & $7-8$ & $9-10$ & 12 & 1,5 \\
C. magister & 4 & 6 & 8 & 10 & 13 & 6 \\
C. productus & 4 & 6 & 8 & 10 & 13 & 5 \\
C. irroratus & 4 & 6 & 8 & 10 & 12 & 5 \\
C. borealis & 4 & 6 & 8 & 10 & 12 & 5 \\
\hline
\end{tabular}

(B)

\begin{tabular}{lclllll}
\hline \hline & $\mathrm{I}$ & $\mathrm{II}$ & $\mathrm{III}$ & $\mathrm{IV}$ & $\mathrm{V}$ & Megalopa \\
\hline C. gracilis & $1,1,1,1$ & $1,1,1,1$ & $1,1,1,1$ & $1,1,1,1$ & $1,1,1,1$ & $1-2$ \\
C. antennarius & $1,1,1,1$ & $1,2,1,1$ & $1,1,1,1$ & $1,1,1,1$ & $1,1,1,1$ & - \\
C. anthonyi & $1,1,1,1$ & $1,1,1$ & $1,1,1,1$ & $1,2,2,1$ & $1,1,1,1$ & - \\
C. amphioetus & $1,1,1,1$ & $1,1,1,1$ & $1,1,1,1$ & $1,1,1,1$ & $1,1,1,1$ & 1 \\
C. magister & $1,1,1$ & $1,1,1$ & $2,1,1,1$ & $1,1,1,1$ & $1,1,1$ & $3,1,1,2,3$ \\
C. productus & $1,1,1,1$ & $1,1,1,1$ & $1,1,1,1$ & $1,1,1,1$ & $1,1,1,1$ & $2,1,2$ \\
C. irroratus & $1,1,1$ & $1,1,1$ & $2,1,1,1$ & $1,1,1,1$ & $1,1,1$ & - \\
C. borealis & - & $1,1,1,1$ & $1,1,1$ & $1,2,2,1$ & $2,1,1,1$ & - \\
\hline
\end{tabular}

\section{Considerations}

As no complete larval descriptions are available as to the European edible crab Cancer pagurus L., that includes five zoeal stages and a megalopa, the data presented by Lebour (1928) and Rice (1975) are unfortunately put aside from the present comparative studies of the larval features. At first, the zoea and megalopa of $C$. magister were compared with those of $C$. productus and then a similar way of comparison was applied to check the larvae of $C$. anthonyi (Poole, 1966; Trask, 1970; Anderson, 1978). The following larval characters were adopted in the above-mentioned comparisons: average length of larvae, spines on the inner margin of telsonal furca, seta on antennule, spines on basal endite of maxillule, spines on coxal endite of maxillule, spines on coxal endite of maxilla, setae on scaphognathite of maxilla, spinal arrangement on endopodite of first maxilliped, setae on exopodite of first maxilliped, and setae on exopodite of second maxilliped. On the other hand, Trask's data on C. magister and $C$. productus were applied independently to check the larvae of $C$. antennarius (Roesijadi, 1976). In this case, the comparison was mainly focused on the following four points: setae on antennal exopodite, spinal arrangement on endopodite of maxillule, setae on exopodite of first maxilliped, and setae on exopodite of second maxilliped. In the present study, all the characters above cited were checked, but 
the average length of the larvae. In addition, comparisons were made in the present study on twenty-one more larval characters.

In zoeae of the eight species of Cancer, the spinal arrangement of 1, 1, 5 from proximal to distal on the endopodite of the second maxilliped is constant through the fifth zoea, while in the megalopa the spinal arrangement is quite variable among the species (Table V and VI, E). Next, the eight species are divisible into two groups by number of setae on the exopodite of the antenna and by number of spines on the endopodite of the maxillule and first maxilliped. The first group comprises $C$. magister, $C$. productus, $C$. irroratus and $C$. borealis, and is characterized by having 3 setae on the antennal exopodite, 6 spines on the endopodite of maxillule and a spinal arrangement of $3,2,1,2,5$ on the endopodite of first maxilliped, while the last group includes $C$. gracilis, $C$. antennarius and $C$. anthonyi, and is definable by having 2 setae, 5 spines and a spinal arrangement of $2,2,1,2,5$ (Table V, A, B and D). C. amphioetus studied in the present paper agrees with the first four species in having 6 spines on the endopodite of the maxillule but with the last three species in having 2 setae on the exopodite of the antenna and the spinal arrangement of 2, 2, 1, 2, 5 on the endopodite of first maxilliped (Table V, A, B and D). By number of spines on the endopodite of the maxilla, the eight species can be divided into the following three groups: the first group, consisting of $C$. gracilis, $C$. antennarius, $C$. anthonyi and $C$. amphioetus, has six spines, the second including $C$. magister and $C$. productus seven spines, and the last composed of $C$. irroratus and $C$. borealis has eight spines (Table V, G).

In contrast with the stability throughout the zoeal stages in the number of setae or spines on certain parts of some appendages above cited, a progressive increase of setae or spines is recognized on the basal and coxal endites of the maxillule and maxilla and also on the exopodite of the maxillipeds. However, any specific pattern can hardly be defined in such an increment and therefore this is unavailable for exact identification of larvae. The aesthetes of the antennule also increase progressively throughout the zoeal stages, but the same number of aesthetes may occur in two or more species.

In the megalopa, the abdominal segments are six and the dactylopodite of the fourth walking leg is furnished with three setae in all the eight species. Further, the same feature in the following larval characters occurs in two or more species: number of setae on the endopodite of the antennule (Table IV, B), number of spines on the basal and coxal endites of the maxillule and maxilla (Table VII and VIII, A, B), number of spines on the exo- and epipodites of the maxillipeds (Table I, B, C and IX and $\mathrm{X}, \mathrm{A})$. On the contrary, the spinal arrangement on the antenna is quite different among the species and available as one of the best characters for exact identification of megalopae, as noted by Anderson (1978). The spinal arrangement on the endopodite of the third maxilliped is seemingly the secondary criterion for the identification of megalopae. Further, the third and fourth clues may be the spinal arrangement on the second and first maxillipeds respectively. The number of setae on the endopodite of the antennule is also variable among the species, but five or six setae occur in two or three species (Table IV, B). 
Summing up the features explained above, it comes to the conclusion that the number of setae or spines on the exopodite of the antenna and those on the endopodite of the maxillule, maxilla and maxillipeds are constant throughout the zoeal stages, while those on the antenna and on the endopodite of the maxillipeds are specific and available as the significant characteristics for exact identification of megalopae.

\section{REFERENCES}

Ally, J.R.R. 1975. A description of the laboratory-reared larvae of Cancer gracilis Dana, 1852 (Decapoda, Brachyura). Crustaceana, 28: 231-246.

Anderson, W.R. 1978. A description of laboratory-reared larvae of the yellow crab, Cancer anthonyi Rathbun (Decapoda, Brachyura), and comparisons with larvae of Cancer magister Dana and Cancer productus Randall. Crustaceana, 34: 55-68.

Iwata, F. 1973. On the first zoea of the crab, Cancer amphioetus Rathbun from Hokkaido, Japan. Proc. Jap. Soc. Syst. Zool., 9: 21-27.

Lebour, M.V. 1928. The larval stages of the Plymouth Brachyura. Proc. zool. Soc. London, 1928: $473-560$.

Poole, R.L. 1966. A description of laboratory-reared zoeae of Cancer magister Dana, and megalopae taken under natural conditions (Decapoda, Brachyura). Crustaceana, 11: 83-97.

Rice, A.L. 1975. The first zoeal stages of Cancer pagurus L., Pinnotheres pisum (Pennant) and Macrophthalmus depressus Rüppell (Crustacea, Decapoda, Brachyura). Bull. Br. Mus. nat. Hist. (Zool.), 28: $237-247$.

Roesijadi, G. 1976. Descriptions of the prezoeae of Cancer magister Dana and Cancer productus Randall and the Iarval stages of Cancer antennarius Stimpson (Decapoda, Brachyura). Crustaceana, 31 : 275-295.

Sastry, A.N. 1977a. The larval development of the rock crab, Cancer irroratus Say, 1817, under laboratory conditions (Decapoda, Brachyura). Crustaceana, 32: 155-168.

1977b. The larval development of the Jonah crab, Cancer borealis Stimpson, 1859, under laboratory conditions (Decapoda, Brachyura). Crustaceana, 32: 290-303.

Trask, T. 1970. A description of laboratory-reared larvae of Cancer productus Randall (Decapoda, Brachyura) and a comparison to larvae of Cancer magister Dana. Crustaceana, 18: 133-146. 